\title{
THE IMPACT OF OBESITY ON DEVELOPMENT OF CARDIOVASCULAR DISEASES - MINI REVIEW
}

\section{EFEKTI GOJAZNOSTI NA NASTANAK KARDIOVASKULARNIH POREMEĆAJA}

\author{
Sanja Soskić', Anastasija Panić', Esma R. Isenovic',1,3,
}

\section{Summary}

Obesity is considered to be a chronic metabolic disorder closely connected to the chronically low inflammation characterized by significant changes in the levels of adipokines and proinflammatory cytokines, as well as other molecules that have an impact on cardiovascular function. Therefore, obesity (especially central obesity) is considered to be a significant risk factor for the development of cardiovascular diseases, atherosclerosis, coronary artery disease, hypertension and left ventricular dysfunction being some of them. The increased accumulation of fat tissue around the heart and in the blood vessels, the increased levels of oxidative stress and the inflammatory state mutually interact in the process of cardiovascular disease occurrence. Lowering the amount of body weight could significantly contribute to reduction of cardiovascular diseases and the subsequent complications.

Key words: obesity, cardiovascular disease.

\section{Sažetak}

Prekomerno prisustvo adipoznog tkiva u organizmu, odnosno gojaznost, predstavlja rezultat energetskog disbalansa, pri čemu unos energije premašuje energetsku potrošnju tokom vremena. Gojaznost se smatra hroničnim metaboličkim poremećajem povezanim sa hroničnom niskom inflamacijom okarakterisanom značajnim promenama nivoa adipokina i proinflamatornih citokina, kao i drugih molekula koji utiču na kardiovaskularnu funkciju. Stoga se gojaznost, posebno centralna gojaznost, smatra značajnim faktorom rizika za nastanak kardiovaskularnih bolesti (KVB), među kojima su ateroskleroza i bolest koronarnih arterija, hipertenzija i disfunkcija leve komore. Povećano nakupljanje masnog tkiva oko srca i krvnih sudova, povećani nivo oksidativnog stresa i inflamatorno stanje međusobno interaguju u procesu nastanka KVB. Smanjenje telesne težine može značajno doprineti smanjenju KVB i njihovih komplikacija. U okviru ovog kratkog preglednog članka, dat je prikaz najnovijih literaturnih podataka o uticaju gojaznosti na nastanak kardiovaskularnih poremećaja.

Ključne reči: gojaznost, kardiovaskularne bolesti

\section{GojAzNost}

Prekomerno prisustvo adipoznog tkiva u organizmu predstavlja gojaznost koja može dovesti do mnogobrojnih zdravstvenih problema $[1,2]$. Gojaznost u svojoj osnovi predstavlja rezultat energetskog disbalansa, pri čemu unos energije premašuje energetsku potrošnju tokom vremena [3]. Gojaznost je peti od vodećih uzroka smrti na svetskom nivou [8] prema podacima Svetske Zdravstvene Organizacije (WHO; engl. World Health Organization) i sa sobom nosi povećan rizik od nastanka metaboličkog sindroma, dijabetesa, kardiovskularnih i malignih bolesti [9]. Gojaznost, posebno centralna gojaznost per se smatra se značajnim faktorom rizika za nastanak kardiovaskularnih bolesti (KVB) i smatra se hroničnim metaboličkim poremećajem povezanim sa hroničnom niskom inflamacijom koju karakterišu značajne promene nivoa adipokina i proinflamatornih citokina, kao i drugih molekula koji utiču na kardiovaskularnu funkciju [4]. Smatra se da će 2015. godine u svetu biti 2,3 milijarde osoba sa prekomernom težinom i više od 700 miliona gojaznih osoba [5]. Učestalost gojaznosti se progresivno povećava, čak i u populaciji starijih ljudi [6]. Gojaznost je jedan od najvažnijih zdravstvenih problema u Srbiji sa učestalošću od 54\%, a najveće prisustvo prekomerne težine je uočeno u populaciji Vojvodine (58\%) [7]. U nekoliko meta-analiza jasno je uočeno da su mortalitet i morbiditet asocirani sa prekomernom telesnom težinom i gojaznošću samo kada je indeks telesne mase (BMI; engl. body mass index) veći od $30 \mathrm{~kg} / \mathrm{m}^{2}$ [6].

\section{GOJAZNOST I KARDIOVASKULARNI POREMEĆAJI}

Gojaznost je nezavisni uzročnik bolesti koronarnih arterija [10]. Gojazni muškarci stariji od 50 godina imaju duplo veći rizik od nastanka koronarnih bolesti, a takođe i gojazne žene približnih godina imaju 2,4 puta veći rizik [13]. Gojaznost dovodi do povećanog nakupljanja perivaskularne masti oko srca i njegovih glavnih krvnih 
sudova [10]. Ovo povećanje adipoznog tkiva oko krvnih sudova uzrokuje prekomerno stvaranje proinflamatornih citokina dovodeći do inflamacije i ateroskleroze sa istovremenim povećanjem zadebljanja intime-medie i smanjenja elastičnosti arterija [14]. Eksperimentalne studije pokazuju da čak i u ranim stadijumima gojaznosti postoji redukcija vazorelaksacije koronarnih arterija zavisne od endotela [15]. Akutni koronarni sindromi su obično aktivirani rupturom ili erozijom ateromatoznog plaka. Kada dođe do rupture plaka, faktor endotelnog tkiva je izložen krvi i pokreće kaskadu koagulacije uzrokujući formiranje tromba [11].

Učestalost hipertenzije kod gojaznih pacijenata je u porastu i osobe sa indeksom telesne mase (BMI, engl. body mass index) većim od 40 imaju sedam puta veću šansu da postanu hipertenzivne [16]. Poznato je da gojaznost kod dece i adolescenata takođe dovodi do hipertenzije [10]. Chiolero i saradnici su sproveli studiju učestalosti hipertenzije i pokazali da kod osoba sa prekomernom težinom i gojaznih ima $37 \%$ pojave hipertenzije [17]. U Švajcarskoj su Maggio i saradnici pokazali pozitivne asocijacije između gojazne dece i sistolne hipertenzije kod $47,6 \%$ pacijenata kao i povećanje mase leve komore delom uzrokovane visokim sistemskim krvnim pritiskom [18]. Gojazna deca imaju 10 puta veći rizik od nastanka hipertenzije kad odrastu u odnosu na normalno uhranjenu decu, a takođe je potvrđena i kontinualna veza između BMI i arterijskog pritiska [19,20]. Stabouli i saradnici [21] su pokazali da gojazni adolescenti imaju viši krvni pritisak i veće zadebljanje intime-medie karotidne arterije u poređenju sa normalno uhranjenim adolescentima. Danas se smatra da je inflamatorno stanje povezano sa gojaznošću je verovatno jedan od faktora odgovornih za hipertenziju [22]. Inflamatorno stanje dovodi do hiperinsulinemije, rezistencije na insulin, dislipidemije i oksidativnog stresa sa pratećim ozbiljnim oštećenjem sistema organa [10].

Povećanje nivoa slobodnih masnih kiselina praćeno povećanim nivoom cirkulišuće glukoze pomaže sekreciju insulin iz pankreasa rezultujući hiperinsulinemijom [10]. Ovi događaji mogu uzrokovati povećanu reapsorciju natrijuma i aktivnost simpatičkog nervnog sistema sa kasnijim razvojem ili pogoršanjem hipertenzije [23]. Aktivacija sistema renin-angiotenzin-aldosteron takođe značajno doprinosi hipertenziji kod gojaznih osoba $[12,24]$. Adipozno tkivo je sposobno da sintetiše komponente ovog sistema $[12,24]$. U vezi sa tim, stvaranje angiotenzina II u adipoznom tkivu povećava produkciju proinflamatornih citokina $[12,13]$ i stimuliše per se vazokonstrikciju, proliferaciju glatkomišićnih vaskularnih ćelija i disfunkciju endotela [22]. Pored angiotenzina II, takođe i povećanje nivoa aldosterona može dovesti do rasta tkiva miokarda [24].

Višak telesne težine povezan je sa slabošću srca i smrću [10]. Za svaku vrednost BMI iznad 30 rizik od nastan- ka slabosti srca se povećava za 5\% kod muškaraca i za $7 \%$ kod žena [13]. Gojaznost je povezana i sa sistolnom i dijastolnom disfunkcijom srca [10]. U unakrsnoj studiji Ammar i saradnici su pokazali postojanje izrazite korelacije između sistolne i dijastolne disfunkcije leve komore i centralne gojaznosti merene odnosom struk/ kuk (WHR, engl. waist-to-hip ratio) [25]. Veće šanse za preživljavanje događaja na srcu imaju pacijenti sa smanjenom količinom izbačene krvi iz leve komore i sa većim BMI od onih sa manjim BMI što je poznato kao "paradoks gojaznosti" [10]. "Paradoks gojaznosti" ili "reverzna epidemiologija" se objašnjava povećanjem dokaza da pacijenti sa povećanim BMI imaju bolje šanse od drugih kada razviju kardiovasularnu bolest ili bolest bubrega [26]. Kapoor i Heidenreich su nedavno pokazali da je stopa mortaliteta kod oboljenja srca povećana kod gojaznih pacijenata sa BMI većim od 45 u poređenju sa normalno uhranjenim osobama [27]. Šta više, u studiji sa 1790 pacijenata Frankenstein i saradnici su otkrili da "paradoks gojaznosti" kod pacijenata sa stabilnom slabošću srca ne postoji posle poklapanja po kliničkim karakteristikama i težini bolesti [28].

\section{ZAKLJUČAK}

Kardiovaskularne bolesti predstavljaju vodeći uzrok mortaliteta kako u savremenom svetu, tako i kod nas. Stoga je upoznavanje mehanizama njihovog nastanka postalo jedna od najvažnijih polaznih tačaka u prevenciji i lečenju KVB. Brojni faktori rizika učestvuju u većoj ili manjoj meri u razvoju KVB, među kojima gojaznost zauzima značajno mesto. Kod gojaznih osoba se češće susreću dobro poznati konvencionalni i nekonvencionalni faktori rizika, a i sama gojaznost per se vrši značajan uticaj na promenu unutrašnje sredine, što može dovesti do ranije i ozbiljnije manifestacije KVB. Povećano nakupljanje masnog tkiva oko srca i krvnih sudova, povećani nivo proinflamatornih citokina i nivoa slobodnih masnih kiselina, kao i povećanje oksidativnog stresa, dovode do ubrzavanja procesa ateroskleroze i češće pojave ishemijske bolesti srca. S druge strane, povećanje volumena cirkulišuće tečnosti kod gojaznih osoba, kao i hiperinsulinemija, povećana aktivnost simpatičkog nervnog sistema i povećana aktivacija rennin-angiotenzin-aldosteron sistema, uz porast reapsorpcije natrijuma, dovode do češće pojave arterijske hipertenzije. Takođe, dokazano je da stepen gojaznosti značajno korelira sa pojavom sistolne i dijastolne disfunkcije srca i ranijom pojavom kongestivne srčane insuficijencije. Jednostavna modifikacija životnih navika uz smanjenje telesne težine može značajno doprineti smanjenju KVB i njihovih komplikacija. 


\section{Literatura}

1. www.who.int/topics/obesity.

2. Sudar, E, et al. "Gojaznost, rezistencija na insulin i kardiovaskularna oboljenja.” Medicinska istraživanja (2012) 46 (2): 54-59.

3. Greener, J., Douglas, F., and van Teijlingen, E. "More of the same? Conflicting perspectives of obesity causation and intervention amongst overweight people, health professionals and policy makers." Soc Sci Med (2010) 70 (7): 1042-1049.

4. Sudar, M. E., et al. "Obesity as a risk factor for cardiovascular diseases: one of the biggest problems in health care today." Life safety and security (2013) 1 (2).

5. Schafer, K., and Konstantinides, S. V. "Update on the cardiovascular risk in obesity: endocrine and paracrine role of the adipose tissue." Hellenic J Cardiol (2011) 52 (4): 327-336.

6. Mathus-Vliegen, E. M., and Obesity Management Task Force of the European Association for the Study of Obesity. "Prevalence, pathophysiology, health consequences and treatment options of obesity in the elderly: a guideline.” Obes Facts (2012) 5 (3): 460-483.

7. Grujic, V., et al. "Overweight and obesity among adults in Serbia: results from the National Health Survey." Eat Weight Disord (2010) 15 (1-2): e34-42.

8. www.who.int/mediacentre/factsheets.

9. Dobutovic, B., et al. "Pathophysiology of obesity". Medicinska istraživanja (2012) 46 (1): 44-54

10. Barbosa, J. A., et al. "Cardiovascular dysfunction in obesity and new diagnostic imaging techniques: the role of noninvasive image methods." Vasc Health Risk Manag (2011) 7: 287-295.

11. Darvall, K. A., et al. "Obesity and thrombosis." Eur J Vasc Endovasc Surg (2007). 33 (2): 223-233.

12. Wassink, A. M., Olijhoek, J.K., and Visseren, F.L. "The metabolic syndrome: metabolic changes with vascular consequences." Eur J Clin Invest (2007) 37 (1): 8-17.

13. Mathew, B., et al. "Obesity: effects on cardiovascular disease and its diagnosis." J Am Board Fam Med (2008) 21 (6): 562-568.

14. Gustafson, B. "Adipose tissue, inflammation and atherosclerosis." J Atheroscler Thromb (2010) 17 (4): 332-341.

15. Galili, O., et al. "Early experimental obesity is associated with coronary endothelial dysfunction and oxidative stress." Am J Physiol Heart Circ Physiol (2007) 292 (2): H904-911.
16. Good, D., et al. "Obesity, hypertension, and the heart." J Cardiometab Syndr (2008) 3 (3): 168-172.

17. Chiolero, A., et al. "Prevalence of hypertension in schoolchildren based on repeated measurements and association with overweight." J Hypertens (2007) 25 (11): 2209-2217.

18. Maggio, A. B., et al. "Associations among obesity, blood pressure, and left ventricular mass." J Pediatr (2008) 152 (4): 489-493.

19. Jolliffe, C. J., and Janssen, I. "Vascular risks and management of obesity in children and adolescents." Vasc Health Risk Manag (2006) 2 (2): 171-187.

20. Ippisch, H. M., et al. "Reversibility of cardiac abnormalities in morbidly obese adolescents." J Am Coll Cardiol (2008) 51 (14): 1342-1348.

21. Stabouli, S., et al. Adolescent obesity is associated with high ambulatory blood pressure and increased carotid intimal-medial thickness. J Pediatr (2005) 147 (5): 651-656.

22. Hadi, H. A., Carr, C.S., and Al Suwaidi, J. "Endothelial dysfunction: cardiovascular risk factors, therapy, and outcome." Vasc Health Risk Manag (2005) 1 (3): 183-198.

23. Aronne, L. J., Nelinson, D. S., and Lillo, J. L. "Obesity as a disease state: a new paradigm for diagnosis and treatment." Clin Cornerstone (2009) 9 (4): 9-25; discussion 26-29.

24. Morse, S. A., et al. "Hypertension and the metabolic syndrome." Am J Med Sci (2005) 330 (6): 303-310.

25. Ammar, K. A., et al. "Central obesity: association with left ventricular dysfunction and mortality in the community." Am Heart J (2008) 156 (5): 975-981.

26. Morse, S. A., Gulati, R., and Reisin, E. "The obesity paradox and cardiovascular disease." Curr Hypertens Rep (2010) 12 (2): 120-126.

27. Kapoor, J. R., and Heidenreich, P.A. "Obesity and survival in patients with heart failure and preserved systolic function: a U-shaped relationship." Am Heart J (2010) 159 (1): 75-80.

28. Frankenstein, L., et al. "The obesity paradox in stable chronic heart failure does not persist after matching for indicators of disease severity and confounders." Eur J Heart Fail (2009) 11 (12): 1189-1194. 